\title{
KONSEP ONTOLOGI DALAM EKONOMI ISLAM
}

\author{
Desy Lidya Alsha ${ }^{1}$, Husni Thamrin ${ }^{2}$ \\ *1\&2Program Studi Ekonomi Syariah Program Pascasarjana \\ Universitas Islam Negeri Sultan Syarif Kasim Riau
}

Email: desylidyaalsha99@gmail.com; husni2017husni@gmail.com

\begin{abstract}
Abstrak: Penelitian ini dilatarbelakangi maraknya perkembangan ekonomi Islam. Perkembangan ini dikarenakan kesadaran dari masyarakat muslim yang semakin tinggi untuk melaksanakan syariat Islam khususnya dalam bidang ekonomi, sehingga penting bagi masyarakat untuk mengetahui hakikat dari ilmu ekonomi Islam agar ilmu tersebut dapat diterapkan dalam kehidupan sehari-hari. Oleh karena itu, penulis tertarik untuk mengkaji mengenai ontologi ekonomi Islam. Rumusan masalah dari penelitian ini adalah bagaimana konsep ontologi ekonomi Islam. Tujuan penelitian ini adalah untuk mengetahui konsep ontologi ekonomi Islam. Jenis penelitian yang digunakan adalah penelitian kepustakaan, dan metode yang digunakan adalah deskripsi dan analisa. Hasil dari penelitian ini menunjukkan bahwa ontologi adalah ilmu yang membahas tentang hakikat apa yang dikaji. Pendekatan ontologis dijadikan sebagai rujukan untuk menentukan hakikat dari ilmu ekonomi Islam. Ilmu ekonomi Islam adalah bagian dari ilmu fiqih muamalah. Ilmu ekonomi Islam membahas dua bidang ilmu secara bersamaan, yaitu ilmu ekonomi murni dan ilmu fiqih muamalah.
\end{abstract}

Kata Kunci : Ontologi, Ekonomi Islam. 


\section{PENDAHULUAN}

Islam menuntut umatnya untuk mengamalkan ajaran Islam secara komprehensif dari segala aspek kehidupan baik politik sosial dan budaya. Dalam kehidupan sehari-hari, ekonomi merupakan roda kehidupan sebagai tempat pemenuhan kebutuhan material manusia, baik secara individu maupun sosial. Pembahasan ekonomi saat ini tidak terlepas dari ekonomi Islam yang terus mengalami perkembangan. Hal ini dikarenakan kesadaran dari masyarakat Muslim yang semakin tinggi untuk melaksanakan syariat Islam khususnya dalam bidang ekonomi yang menjadikan mereka berusaha menerapkan ekonomi Islam di dalam kehidupannya.

Ilmu ekonomi sebagai cabang ilmu sosial memiliki karakteristik yang khas khususnya tentang upaya manusia untuk memenuhi kebutuhannya dari sumber daya alam yang terbatas namun keinginan manusia tidak terbatas. Disinilah, letak filsafat ekonomi, ia bukan hanya mempersoalkan aktivitas ekonomi yang dilakukan oleh manusia namun juga menggali nilai-nilai yang dianut oleh mereka.

Filsafat ekonomi Islam adalah cabang dari ilmu filsafat yang mengkaji mengenai aktifitas ekonomi Islam. Filsafat sebagai sebuah cabang ilmu mempelajari semua hal di dunia, termasuk aktifitas yang dilakukan oleh manusia yaitu ekonomi. Kunci filsafat ekonomi Islam terletak pada manusia dengan tuhan, alam, dan manusia lainnya. Dimensi filsafat inilah yang membedakan ekonomi Islam dengan sistem ekonomi kapitalisme dan sosialisme. Salah satu dasar yang menjadi perbedaan antara sistem ekonomi Islam dengan sistem ekonomi lainnya terletak pada falsafahnya, yang terdiri dari nilai-nilai, etika, dan tujuan yang ada.

Ekonomi Islam lebih jauh membahas nilai-nilai serta etika yang ada dalam setiap kegiatan ekonomi yang selalu mendasari setiap kegiatannya, sedangkan sistem ekonomi lain hanya fokus pada hukum dan sebab akibat dari suatu kegiatan ekonomi (Misno, 2020 : 20-22).

Sesuatu dianggap sebagai sebuah ilmu pengetahuan jika memenuhi tiga aspek yakni aspek ontologi, epistemologi, dan aksiologi. Ketiga aspek filsafat ilmu ini juga disebut sebagai metode ilmiah, yaitu metode atau prosedur yang digunakan untuk mengukur ilmu/ pengetahuan. Ontologi menjelaskan tentang hakikat sebuah ilmu. Ontologi membahas mengenai hakikat apa yang dikaji.

Di bidang ontologis, liberalisme berpandangan bahwa manusia pada dasarnya adalah bebas melakukan apa saja, termasuk dalam bidang ekonomi. Mereka memiliki hak untuk mengembangkan usahanya, hak untuk menggunakan tenaga kerja dan hak untuk memiliki peralatan produksi. Disisi lain sosialisme mempunyai pandangan yang berbeda bahwa, dalam iklim kebebasan pada kapitalisme ada kontradiksi sosial, yakni kontradiksi hubungan kerja antara majikan dan budak/buruh (Damsar dan Indrayani, 2016 : 36).

Ada pandangan yang sama antara kapitalisme dan sosialisme. Keduanya lahir dalam budaya Barat. Menurut Syed Naquib al Attas, budaya Barat memiliki perbedaan yang sangat jelas dengan Islam yaitu perbedaan pandangan hidup (world view). Apabila Islam pada umumnya menempatkan pandangan hidupnya semata-mata untuk allah (theosentris), sebaliknya pandangan Barat 
menempatkan pandangan hidupnya pada hal-hal yang bersifat empiris (Ismail , 2016 :116).

Pandangan hidup sering diistilahkan dengan worldview, yang meliputi segala sistem dalam kehidupan setiap orang, baik itu politik, ekonomi, sosial maupun kebudayaan. Worldview (pandangan hidup) dalam kehidupan sehari-hari seorang muslim, diwujudkan dengan keyakinan akan adanya Allah, malaikat, para nabi-nabinya, serta aturanaturan Allah yang disampaikan melalui nabi yang disebut dengan syariah. Keyakinan akan kebenaran Islam ini diwujudkan dalam ekonomi, seperti menjauhi riba dan rentenir, menghindari konsumsi barang yang diharamkan, tidak mengurangi takaran dalam berdagang, dan sebagainya (Muheramtohadi, 2018 : 80).

Secara ontologis, ilmu ekonomi Islam membahas dua bidang ilmu secara bersamaan yaitu ilmu ekonomi murni dan fiqh muamalat. Akibatnya, ilmu ekonomi Islam selalu berasal dari dua bidang keilmuan tersebut dalam melakukan kegiatannya (Zaini, dan Abdullah Zawawi,2019 : 58).

Sebagai cabang ilmu yang baru filsafat ontologi ekonomi Islam harus terus dikembangkan agar ke depannya menjadi satu cabang ilmu yang bermanfaat bagi umat Islam. Berdasarkan pembahasan di atas, maka ontologi ekonomi syariah menarik untuk dikaji karena melihat perkembangan ekonomi Islam yang saat ini semakin berkembang, dan juga untuk mengetahui hakikat dari ilmu tersebut. Dari latar belakang masalah yang telah dijelaskan di atas, maka penulis tertarik untuk menulis mengenai "Konsep Ontologi Dalam Ekonomi Islam".

\section{TINJAUAN PUSTAKA \\ Pengertian Ontologi}

Ontologi bersumber dari bahasa Yunani yakni 'Ontos' yang memiliki pengertian adalah sebagai suatu yang sungguh-sungguh ada serta adanya itu benar, atau juga kenyataan yang sesungguhnya. Sementara untuk 'logos' memiliki arti ilmu pengetahuan atau ajaran atau juga pemikiran. Banyak tokoh yang menjelaskan tentang pengertian dari ontologi. Salah satunya, menurut Suriasumantri yang menjelaskan bahwa ontologi adalah suatu pembahasan tentang apa yang ingin kita ketahui, seberapa jauh kita ingin tahu, atau dengan kata lain suatu kajian terhadap teori tentang ada (Misno, 2020 : 30-31).

Ontologi adalah bidang utama filsafat yang mempertanyakan esensi keberadaan segala sesuatu yang ada, menurut tata hubungan secara sistematis berdasarkan hukum sebab akibat, yaitu ada manusia, alam, dan causa prima dalam suatu hubungan menyeluruh, tertib dan teratur dalam keharmonisan (Putra, dan Ami Dilham, 2016: 16). Ontologi mengungkap tentang hakikat apa yang dikaji, atau dengan kata lain, ontologi adalah science of being qua being. Pendekatan ontologis digunakan sebagai pedoman untuk mendefinisikan hakikat ekonomi Islam.

Dalam pembahasan ontologi, manusia dihadapkan pada pertanyaan bagaimana menjelaskan hakikat segala sesuatu yang ada. Manusia dihadapkan pada dua macam kenyataan untuk pertama kalinya. Yang pertama adalah kenyataan berupa materi (kebenaran) dan yang kedua adalah kenyataan rohani (kejiwaan) (Bakhtiar, 2014 : 131-134).

Oleh karena itu, ontologi dapat diartikan sebagai ilmu atau teori tentang wujud hakikat yang ada dalam ilmu. 
Penyelidikan tentang keilmuan dan hakikat objek ilmu (Misno, 2020 : 31).

\section{METODE PENELITIAN}

Jenis penelitian yang digunakan adalah penelitian kepustakaan. Penelitian kepustakaan (library research) adalah penelitian yang dilakukan dengan menggunakan kepustakaan (library) berupa buku, catatan, dan laporan hasil penelitian sebelumnya. Sedangkan metode yang digunakan adalah deskripsi dan analisa (P Fathurrahman, 2011 : 31).

\section{PEMBAHASAN}

\section{Ontologi Ekonomi Islam}

Ontologi adalah kajian untuk menentukan hakikat dari ilmu ekonomi Islam. Secara ontologis, ekonomi Islam pada hakikatnya adalah bersumber dari Al-Qur'an dan Hadis. Al-Qur'an dan Hadis sebagai sumber ilmu ekonomi Islam ini adalah bersifat mutlak. Kebenaran dalam Al-Qur'an berbeda dengan hakikat kebenaran dalam sistem ekonomi konvensional. Hakikat ekonomi Islam dapat dijelaskan sebagai berikut :

1. Kekayaan alam cukup untuk memenuhi kebutuhan manusia.

Allah bersifat Maha pencipta, Maha Perencana, Maha Mengetahui dan Maha Pemelihara dalam menciptakan alam semesta, yang tentunya sudah memperhitungkan kebutuhan-kebutuhan yang ada dalam alam semesta. Allah akan memelihara alam semesta ini sampai akhir zaman. Kebutuhan bagi makhluk hidup yang ada di bumi telah disediakan dengan cukup. Pandangan ini sangat bertolak belakang dengan teori ekonomi konvensional yang menyatakan bahwa alat pemuas kebutuhan manusia terbatas.
2. Kebutuhan manusia dicukupi dan telah diatur.

Ajaran Islam berpandangan bahwa kebutuhan manusia sudah dirancang. Kekayaan seseorang dalam pandangan Islam selama ini berbeda pandangan dengan pemahaman umum masyarakat. Islam memandang bahwa kekayaan seseorang adalah kekayaan yang dinikmati dan bukan kekayaan yang dimiliki.

Jumlah kekayaan yang dimiliki manusia biasanya lebih banyak daripada jumlah kekayaan yang dinikmati. Mengejar kekayaan adalah salah satu dari dampak hukum ekonomi konvensional yang mendominasi pemikiran masyarakat.

3. Pembatasan konsumsi.

Konsumsi telah diatur dalam agama Islam sebagaimana Allah Swt telah memberi kesempatan umat manusia untuk memenuhi kebutuhannya melalui rezeki yang telah dikaruniakan. Jumlah yang dikonsumsi oleh manusia tidak boleh berlebihan, boros dan sematamata hanya untuk memenuhi hawa nafsu. Dalam Al-Qur'an sudah dijelaskan bahwa tindakan boros dalam konsumsi sangat dilarang. Perilaku boros dan berlebihan dilarang bukan karena alam akan habis akibat pemakaian oleh manusia tetapi lebih didasarkan pada efek dari perilaku manusia yang konsumtif.

4. Produksi.

Aktivitas produksi dalam Islam merupakan tindakan yang mulia, seperti yang digambarkan dalam hadis nabi mengenai aktivitas bercocok tanam merupakan suatu 
tindakan sedekah. Hasil dari bercocok tanam adalah suatu barang baru yang bermanfaat bagi kelangsungan hidup makhluk. Bercocok tanam dapat dianalogikan kegiatan produksi yaitu menghasilkan barang dan jasa untuk memenuhi kemanfaatan bagi kebutuhan manusia.

5. Distribusi kekayaan.

Kekayaan dalam Islam harus didistribusikan kepada semua orang, dan jangan hanya beredar pada orang-orang kaya. Ajaran Islam mengenal mekanisme penyebaran kekayaan melalui zakat, infaq, dan shodaqoh.

6. Islam melarang riba.

Hakikat ekonomi Islam dengan ekonomi konvensional berbeda jauh dan sangat bertolak belakang. Hakikat ekonomi konvensional dibangun dengan pendekatan provokatif. Sedangkan ekonomi Islam dibangun dengan pendekatan ketentraman dan kebahagiaan (Agriyanto, dan Abdul Rohman, 2015 : 45-49).

Hakikat atau ontologi dari ekonomi Islam adalah sistem ekonomi yang didasarkan kepada wahyu Ilahi, ia bukan hanya mengatur tata cara seseorang dalam memenuhi kebutuhannya namun juga menempatkannya sebagai hamba Allah ta'ala. Dalam konteks ini maka hakikat dari ekonomi Islam adalah bahwa semua aktivitas harus dikembalikan kepada allah ta'ala.

Maka Allah ta'ala sebagai zat yang ada menjadi asas dalam setiap aktivitas ekonomi. Keyakinan mendalam akan keberadaannya menjadikan manusia harus tunduk patuh terhadap seluruh aturannya, termasuk dalam masalah ekonomi. Semua aktivitas ekonomi didasarkan pada keyakinan ini dan mengikuti setiap yang ada dalam wahyu darinya.

Adapun secara teknis maka manusia diberikan kebebasan untuk melaksanakan dengan sebaik-baiknya segala aktivitas ekonomi tanpa meninggalkan fungsinya sebagai khalifah di muka bumi. Maknanya, walaupun dasarnya adalah keyakinan akan keberadaan-Nya namun tetap memperhatikan kebutuhan dari manusia sendiri. Hal ini karena pada dasarnya pula seluruh aturan (syariah) Allah ta'ala adalah ditujukan untuk kebaikan manusia.

Pada hakikatnya ekonomi Islam ialah sistem ekonomi yang didasarkan kepada nilai-nilai Islam. Sistem ekonomi ini bersandarkan kepada wahyu Ilahi yang terdapat di dalam Alquran dan AsSunnah. Apabila tidak ada dalil syar'i pada keduanya maka digunakan metode ijtihad dalam bentuk ijma,' qiyas, istishab, maslahah, syar'u man qablana, qaul shahbi, dan 'urf'.

Ilmu Ekonomi Islam adalah cabang dari dua disiplin ilmu yang awalnya berbeda yaitu ilmu ekonomi dan ilmu Islam. Sebagai disiplin ilmu baru ilmu ekonomi Islam adalah gabungan dari ilmu ekonomi murni dan ilmu-ilmu keislaman khususnya fiqih Islam atau muamalah. Kombinasi dari kedua ilmu ini memunculkan disiplin ilmu baru yang khas dan berbeda dengan ilmu sebelumnya.

Ilmu ekonomi Islam merupakan pengembangan dari ilmu fiqh khususnya fiqh muamalah. Berikut adalah bagan eksistensi dari ilmu ekonomi Islam: 


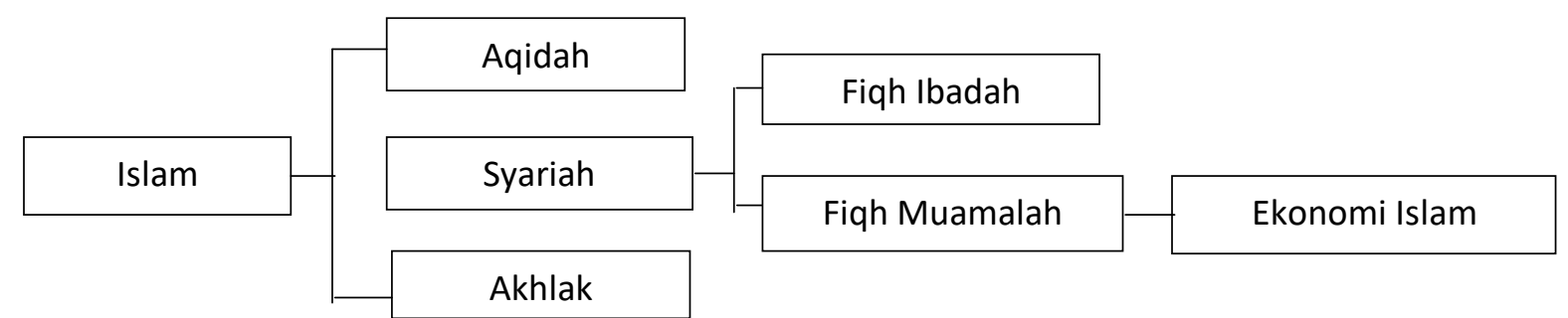

Ilmu ekonomi Islam dalam konteks ilmu ekonomi adalah sebagai ilmu ekonomi berbasis etika. Ia adalah ilmu ekonomi yang bersifat normatif. Menurut Hoetoro, makna normatif adalah pernyataan yang cenderung didasarkan kepada penilaian tertentu, dan menaruh perhatian tentang apa yang seharusnya terjadi. Sedangkan pernyataan positif menjelaskan realitas berdasarkan analisis logis dan eksperimen (Misno, 2020 : 3536).

Ekonomi Islam dalam bahasa Arab diistilahkan dengan al-iqtishad al-islami. Al-iqtishad secara bahasa berarti alqashdu yaitu berkeadilan dan pertengahan. Pengertian berkeadilan dan pertengahan ini banyak ditemukan dalam Al-Qur'an diantaranya dalam Surah Luqman ayat 19 yang berbunyi:

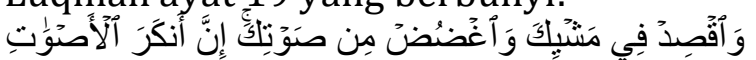

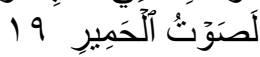

Artinya: "Dan sederhanalah kamu dalam berjalan" (Luqman :19)

Dan dalam Surah Al-Maidah ayat 66:

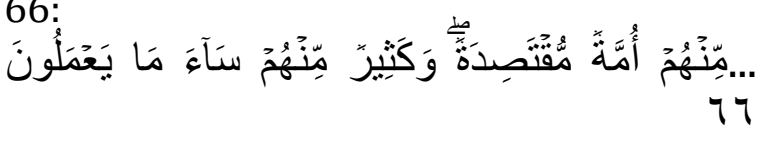

Artinya:" Di Antara mereka ada golongan yang pertengahan" (Al-Maidah :66). Maksudnya orang yang berlaku jujur, lurus, dan tidak menyimpang dari kebenaran (Misno, 2020 : 15).

Kesimpulan ontologi ekonomi Islam dan ciri-cirinya adalah cara pandang baru terhadap masalah dan fenomena realitas ekonomi, seperti mengidentifikasi penyebab masalah ekonomi yang mengarah pada "maqashid syariah" dan tujuan ekonomi untuk menuju "falah" (Alam, 2016 : 65).

\section{Perbedaan Ontologi Ekonomi Islam dengan Ontologi Ekonomi Konvensional}

Dalam penerapannya ilmu ekonomi Islam akan selalu berasal dari kedua disiplin ilmu yakni ilmu fiqh muamalat dan ilmu ekonomi murni, dan masalah ontologis yang timbul adalah bagaimana menggabungkan antara pemikiran ekonomi sekuler dengan pemikiran yang sakral dalam fiqh muamalat. Masalah ini muncul mengingat sumber ilmu ekonomi adalah pemikiran manusia sementara sumber fiqh muamalat adalah wahyu yang berdasarkan ajaran Al-Qur'an dan hadits Nabi.

Perbedaan sumber ilmu pengetahuan ini menyebabkan timbulnya penilaian yang berbeda terhadap masalah ekonomi manusia. Misalnya, ilmu ekonomi akan menciptakan sistem ekonomi liberal, kapitalis dan komunis sejauh itu dapat memenuhi kebutuhan hidup manusia. Akan tetapi, fiqh muamalat tidak serta merta menerima ketiga sistem tersebut karena masih diperlukannya legislasi dari Al-Qur'an dan Hadits (Akbar, dan Rika Lidyah, 2013 : 73).

Di sisi lain, teori kebenaran ilmu ekonomi dan ilmu fiqih muamalat tentu saja bertolak belakang. Kriteria 
kebenaran dalam ilmu ekonomi selalu mengarah kepada tiga teori kebenaran yang digunakan dalam filsafat ilmu yaitu teori koherensi (kesesuaian dengan teori yang sudah ada), teori korespondensi (kesesuaian dengan fenomena yang ada), dan teori pragmatisme (kesesuaian dengan kegunaannya).

Sedangkan teori kebenaran fiqh muamalat secara tegas mengacu pada wahyu allah. Maksudnya, kesepakatan dalam ekonomi dianggap benar jika tidak ada larangan dalam wahyu. Berdasarkan perbedaan sumber pengetahuan dan teori kebenaran yang diterapkan tentu saja sulit untuk menggabungkan ilmu ekonomi dan fiqh muamalat bahkan secara nyata diakui bahwa pemberlakuan sistem ekonomi Islam dibidang perbankan dan asuransi identik dengan yang terdapat dalam sistem ekonomi konvensional (Zaini, dan Abdullah Zawawi,2019 : 53).

Ekonomi barat jelas tidak berlandaskan pada kepercayaan akan adanya wahyu, dimana akal dan pikiran harus tunduk padanya. Paradigma yang dibangun adalah bahwa baik dan buruk itu datangnya dari manusia itu sendiri, juga menganut pemahaman bahwa agama tidak boleh mengatur masalah etika. Karena keyakinan itu adalah masalah privasi, maka agama hanya lah menyangkut masalah hubungan dirinya sendiri dengan tuhan nya, agama tidaklah boleh mengatur hubungan antar manusia. Paradigma ilmiah Barat didasarkan pada nalar atau akal, sebagai sarana untuk melakukan penalaran filosofis. Maksudnya ialah, apakah dunia ini berwujud dari ide- ide (idealis), atau hanya berwujud materialis (materi belaka) tergantung pada penalaran spekulatif. Barat cenderung mengandalkan sesuatu pada kinerja otak melalui logika, matematika, atau dialektika untuk fokus pada hal-hal tertentu, sehingga menghilangkan hal yang sifatnya spiritual, dan cenderung bersikap ragu terhadap segala sesuatu yang sifatnya ghaib. Tentunya ini berbeda dengan Islam, yang menempatkan landasan ontologisnya pada wahyu Allah bukan pada rasio.

Di sisi lainnya, terdapat banyak orang Islam yang menggunakan paradigma barat. Mereka banyak mengambil pemikiran sosialisme dan liberalisme dari barat yang tidak selamanya berkesesuaian dengan Islam, maka lahirlah pencampuran yang mengakibatkan kebingungan (confusion) dalam menentukan posisi dirinya sendiri. Akibatnya, kepercayaan-kepercayaan tentang hal yang ghaib, termasuk urusan nyawa, secara ontologis hanya masalah kinerja fungsi otak semata (Muheramtohadi, 2018 : 81-83).

Landasan ontologi berkaitan dengan gambaran umum tentang struktur realitas yang berlaku secara umum dan mutlak. Ontologi terkait pada dua hal, yang pertama mengenai landasan tentang dunia \& dinamikanya, dan yang kedua tentang hakekat manusia (Wikandaru and Cahyo, 2016 : 128).

Pemikir Barat mengembangkan paham bahwa dunia ini pada dasarnya terjadi oleh mekanisme alam semesta yang terjadi di luar kehendak tuhan, dan berlangsung begitu saja, termasuk bumi dan seisinya. Sedangkan orang sosialis pada umumnya menganggap bahwa evolusi terjadi dari pertarungan memperebutkan sumber makanan (mangsa), dan yang terkuatlah yang menang.

Manusia dalam konsepsi Islam, adalah makhluk ciptaan Allah yang paling sempurna. Ia terlahir secara fitrah (suci), 
dan hal ini tentu saja berbeda dengan konsep liberalis dan sosialis dalam hal ekonomi.

Dalam pemikiran kapitalis, manusia pada dasarnya mencukupi kebutuhannya secara individualistik, maka seluruh proses pengeluaran ekonominya harus berlandaskan pada ukuran yang rasional (perhitungan).

Sedangkan pandangan ontologis Marx, menempatkan hakekat manusia pada kerja. Keterasingan manusia akan hakekatnya, ketika ia dijauhkan dari hasil pekerjaannya. Sehingga, ketika seseorang bekerja untuk orang lain, maka ia dijauhkan dari hakekatnya sendiri (Muheramtohadi, 2018 : 85).

Pandangan ontologis kapitalisme berpegang pada hakekat manusia yang individualistik. Perilaku manusia pada umumnya bertujuan untuk dirinya sendiri. Smith menyatakan bahwa segala kebutuhan yang kita dapat dari membeli, bukan karena keinginan penjual memperhatikan kebutuhan kita, tetapi mereka memperhatikan keuntungankeuntungan diri mereka sendiri, sehingga pemikiran Adam Smith dikembangkan menjadi pemikiran ekonomi yang berpijak pada pemenuhan kebutuhan pribadi/self interest.

Pihak sosialis mengecam sistem kapitalis karena tidak mempedulikan penghormatan atas diri manusia, dan menawarkan sebuah pemikiran negara komunisme. Tetapi pada perkembangan seterusnya, sosialisme dianggap gagal, karena mengabaikan kebebasan individu dalam melakukan aktivitas ekonominya (Adawiyah, 2012:174).

Antara kapitalisme dan sosialisme seolah berbeda satu dengan lainnya, tetapi pada dasarnya mereka digerakkan pada asumsi yang sama, yaitu pandangan mereka tentang spesies manusia, apakah manusia itu bersaing secara egoistik (kapitalis) ataukah bersama-sama tidak ada persaingan. Dari perbedaan penafsiran terhadap hakekat spesies ini, maka muncul lah dua pandangan yang berbeda, sosialis hendak memusnahkan kepemilikan alat produksi agar semua orang bisa berdiri bersama-sama, sedangkan kapitalis tetap mempertahankan alat produksi, karena hakekat dari spesies adalah bersaing.

Sedangkan Islam, menyatakan bahwa perbedaan manusia dalam kemampuan kerja, adalah sunnatullah. Karena manusia sendiri, berbeda menurut jenisnya, terdapat orang yang terampil dan pekerja keras, dan ada pula orang yang tidak terampil dan pemalas. Sehingga, mempengaruhi tingkat pemasukan seseorang.

Kepemilikan atas suatu harta benda, menurut filsafat barat, adalah kepemilikan dalam arti penuh, atau absolut. Sedangkan dalam Islam, kepemilikan absolut hanya pada Allah.

Perbedaan mendasar antara filsafat ekonomi Islam dan ekonomi konvensional adalah bahwa dalam Islam, Allah menciptakan segala sesuatu yang ada di langit dan di bumi untuk manusia. Ini berarti bahwa rizki Allah tidak terbatas. Dengan demikian, dalam ekonomi Islam,barang melimpah, tetapi kemampuan manusia untuk mengelolanya sangat terbatas. Di sisi lain, dalam ekonomi sekuler, jumlah barang (terbatas), sehingga diperlukannya tindakan ekonomis. Tindakan ekonomis, bagi mereka harus berangkat dari penalaran empiris murni. Oleh karena itu, esensi pemikiran Barat adalah anthroposentrisme atau berpusat pada manusia (Muheramtohadi, 2018 : 86-88).

Ilmu ekonomi Islam menelaah halhal yang semestinya dilakukan setiap 
pelaku ekonomi yang sesuai dengan nilainilai Islam. Oleh lantaran itu, sebagian ilmuwan Barat mengelompokkan ilmu ekonomi Islam kepada ilmu pengetahuan normatif. Tetapi jika dilihat berdasarkan hubungan teori ilmu ekonomi Islam dengan realitas yang terjadi, ilmu ini bisa pula digolongkan menjadi ilmu pengetahuan positif .

Atas dasar hal tersebut, ilmu ekonomi Islam termasuk ke dalam ilmu pengetahuan normatif dan positif. Tentu hal ini akan sangat sulit diterima oleh para ilmuwan Barat yang memisahkan dua hal tersebut dalam teori ilmiah mereka.

Para ilmuwan Barat terutama yang beraliran positivisme, menyangkal ilmu ekonomi Islam sebagai sebuah ilmu. Penolakan ini dipengaruhi oleh perbedaan antara pandangan dunia Barat dan Islam. Barat lebih memandang ilmu sebagai sebuah realitas yang ada dan terpisah dari hal-hal yang bernilai moral dan etika. Dan Islam memandang bahwa semua aktivitas manusia di muka bumi ini tidak terlepas dari nilai-nilai ketuhanan (ilahiyah). Ilmu ekonomi Islam harus dipandang sebagai satu kesatuan yang tidak bisa dipisahkan dari sudut pandang positivisme dan normativisme.

Menurut Muhadjir tesis positivisme adalah bahwa ilmu merupakan satu-satunya yang valid, dan hanya fakta yang mungkin dapat menjadi objek pengetahuan. Dengan demikian positivisme menolak keberadaan segala kekuatan atau subyek di belakang fakta, menolak segala penggunaan metode selain yang digunakan untuk memeriksa fakta

Oleh sebab itu, metode dan pendekatan dalam ilmu ekonomi Islam tidak dapat diserupakan dengan metode dan pendekatan yang digunakan dalam pandangan dunia Barat. Semestinya, ilmu ekonomi Islam dapat dipahami dengan menggunakan metode dan pendekatan yang dapat diterima dari sudut pandang Islam. Metode dan pendekatan yang sesuai dengan pandangan Islam akan dapat terbentuk apabila ilmu ekonomi Islam dipahami sebagai satu kesatuan dengan cabang-cabang ilmu pengetahuan Islam lainnya (Misno, 2020 : 37-38).

\section{SIMPULAN}

Ontologi adalah cabang ilmu filsafat yang mengkaji mengenai keberadaan (hakikat) dari sesuatu, dalam konteks ekonomi Islam maka yang dikaji adalah hakikat keberadaan dari ekonomi Islam. Landasan ontologi berkaitan dengan gambaran umum tentang struktur realitas yang berlaku secara umum dan mutlak. Secara ontologis, ilmu ekonomi Islam membahas dua bidang ilmu secara bersamaan yaitu ilmu ekonomi murni dan fiqh muamalat. Ilmu ekonomi Islam menerangkan apa yang harus dilakukan oleh setiap pelaku ekonomi sesuai dengan nilai-nilai Islam. Penerapan sistem ekonomi Islam merupakan bagian integral dari penerapan syari'at Islam sehingga sistem ekonomi Islam merupakan bagian yang tak terlepaskan dengan syari'at-syari'at Islam lainnya.

Kriteria kebenaran dalam ilmu fiqh muamalat secara tegas mengacu pada wahyu Allah, sementara ilmu ekonomi selalu mengarah kepada tiga teori kebenaran yang dipakai dalam filsafat ilmu yaitu kesesuaian dengan teori yang sudah ada (teori koherensi), kesesuaian dengan fenomena yang ada (teori korespondensi), dan kesesuaian dengan kegunaannya (teori pragmatisme). Ilmu ekonomi Islam diatur oleh nilai-nilai dasar dalam Islam, sedangkan ekonomi 
konvensional diatur oleh kepentingan individu.

\section{DAFTAR RUJUKAN}

Adawiah, R. (2013). Perspektif Beberapa Ideologi Tentang Ekonomi (Sebuah Kajian Filsafat Ekonomi). At-Taradhi: Jurnal Studi Ekonomi, $3(2)$.

Agriyanto, R., \& Rohman, A. (2017). Rekonstruksi Filsafat Ilmu Dalam Perspektif Perekonomian Yang Berkeadilan (Kajian terhadap Ontologi, Epistemologi dan Aksiologi Ilmu Ekonomi yang Islami). At-Taqaddum, 7(1), 3553.

Akbar, D. A., \& Lidyah, R. (2013). Kajian Filsafat Ilmu Terhadap Ekonomi Islam. Nurani: Jurnal Kajian Syari'ah Dan Masyarakat, 13(1), 68-90.

Alam, Azhar. (2016). Perkembangan Ekonomi Islam: Perspektif Filosofis. Proceeding of International Conference On Islamic Epistemology, Universitas Muhammadiyah Surakarta.

Damsar, \& Indrayani. (2016). Pengantar Sosiologi Perdesaan. Jakarta: Kencana.

Ismail, Muhammad. (2016). Menalar Makna Berpikir Dalam Al-Qur'an. Ponorogo: Unida Gontor Press.

Misno, Abdurrahman. (2020). Falsafah Ekonomi Syariah. Yogyakarta: Bintang Pustaka Madani.

Muheramtohadi, S. (2018). Perbandingan Antara Filsafat Ekonomi Islam Dan Barat. Jurnal Stie Semarang (Edisi Elektronik), 10(3), 73-92.

Wikandaru, R., \& Cahyo, B. (2016). Landasan Ontologis Sosialisme. Jurnal Filsafat, 26(1), 112-135.
Zaini, A. A., \& Zawawi, A. (2019). Ekonomi Islam Dalam Konsep Ontologi, Epistemologi Dan Aksiologi. Ummul Qura: Jurnal Institut Pesantren Sunan Drajat (INSUD) Lamongan, 14(2), 49-60. 